\title{
Epigallocatechin gallate, a constituent of green tea, suppresses cytokine-induced pancreatic $\beta$-cell damage
}

\author{
Myung-Kwan $\mathrm{Han}^{1}$ \\ Department of Microbiology \\ Chonbuk National University Medical School and \\ Institute for Medical Sciences \\ Jeonju 560-756, Korea \\ ${ }^{1}$ Corresponding author; Tel, 82-63-270-3106; \\ Fax, 82-63-274-9833; E-mail, iamtom@moak.chonbuk.ac.kr
}

Accepted 8 April 2003

Abbreviations: EGCG, epigallocatechin gallate; iNOS, inducible nitric oxide synthase; MTT, 3-4,5-dimethylthiazol-2-yl-2,5-diphenyltetrazolium bromide; NO, nitric oxide

\begin{abstract}
Cytokines produced by immune cells infiltrating pancreatic islets have been implicated as one of the important mediators of $\beta$-cell destruction in insulin-dependent diabetes mellitus. In this study, the protective effects of epigallocatechin gallate (EGCG) on cytokine-induced $\beta$-cell destruction were investigated. EGCG effectively protected IL-1 $\beta$ and IFN- $\gamma$-mediated cytotoxicity in insulinoma cell line (RINm5F). EGCG induced a significant reduction in IL-1 $\beta$ and IFN- $\gamma$-induced nitric oxide (NO) production and reduced levels of the inducible form of NO synthase (iNOS) mRNA and protein levels on RINm5F cells. The molecular mechanism by which EGCG inhibited iNOS gene expression appeared to involve the inhibition of NF-KB activation. These findings revealed EGCG as a possible therapeutic agent for the prevention of diabetes mellitus progression.
\end{abstract}

Keywords: cytokine; epigallocatechin gallate; NF-kB; nitric oxide

\section{Introduction}

Epigallocatechin gallate (EGCG), a major ingredient of green tea has been known to have a variety of physiological activities; anticarcinogenic, antioxidant, antiangiogenic, and antiviral activity (Nakayama et al., 1993; Yang and Wang, 1993; Katiyar and Mukhtar, 1997). In addition, EGCG was also reported to func- tion as antidiabetic. Injection of EGCG into lean and obese Zucker rats significantly lowered blood glucose and insulin levels, and green tea extract increased glucose metabolism in adipocytes (Broadhurst et al., 2000; Kao et al., 2000). Epicatechin, structurally similar to EGCG, is the active compound in the extract from Pterocarpus marsupium Roxb bark traditionally used in Indian folk medicine to treat diabetes (Ahmad et al., 1989).

Insulin-dependent diabetes mellitus (IDDM) develops as a consequence of the selective destruction of insulin-producing $\beta$-cells due to a variety of factors including reactive oxygen species (ROS), toxins (microbial, chemical, dietary), and autoimmune responses (Rabinovitch and Suarez-Pinzon, 1998). Recent studies provided evidences that $\beta$-cells are destroyed by autoimmune responses directed against certain $\beta$-cell constituents (autoantigens). Mediation by cytokines secreted by the infiltrating immune cells was reported to illicit cytotoxicity of pancreatic $\beta$-cell is mediated by cytokines (Rabinovitch and Suarez-Pinzon, 1998; Tannous et al., 2001).

Tannous et al. (Tannous et al., 2001) have demonstrated that cytokine-induced pancreatic $\beta$-cell damage is primarily associated with the induction of inducible nitric oxide synthase (iNOS), leading to the generation of nitric oxide (NO) within the cell, which subsequently causes dysfuction of the pancreatic $\beta$ cell. Together, these results suggest that cytokine-induced up-regulation of iNOS in pancreatic $\beta$-cell may contribute in generation of IDDM, and intervention of iNOS-induction could provide an effective means to prevent or treat onset of the disease.

EGCG known for antioxidative activity may protect cytokine-induced pancreatic $\beta$-cell damage. In this study we used a cytokine-induced $\beta$-cell damage system to examine functional role of EGCG in the prevention of the $\beta$-cell damage. We show that EGCG protected cytokine-induced $\beta$-cell damage, which is partly mediated by suppression of NF-kB or iNOS activity.

\section{Materials and Methods}

\section{Cell culture and EGCG treatment}

The RINm5F pancreatic $\beta$-cell line was purchased from the American Type Culture Collection. RINm5F cells were cultured in RPMI-1640 medium supplemented with $10 \%$ fetal bovine serum. Cells were 
cultured in 24-well plates for 2 days prior to various experimental conditions. The culture medium was replaced with medium consisting of either diluents alone or IL-1 $\beta$ and IFN- $\gamma$. EGCG was purchased from Sigma.

\section{Assessment of cell viability}

Cells were incubated with EGCG at various concentrations of $0,20,50,100$ and $200 \mu \mathrm{g} / \mathrm{ml}$. Thereafter, the cells were treated with IL-1 $\beta$ and IFN- $\gamma$, and the medium was changed, and then 3-4,5-dimethylthiazol-2-yl-2,5-diphenyltetrazolium bromide (MTT); $100 \mu \mathrm{g} / 0.1 \mathrm{ml}$ was added for $4 \mathrm{~h}$. The viable cell number is directly proportional to the production of formazan which, following solublization with DMSO, was measured spectrophotometrically at $570 \mathrm{~nm}$.

\section{Quantitation of nitrite release}

Cell-free supernatants were collected after incubation at each time points. Each sample was added to 96-well plates, and NO production was measured as nitrite $\left(\mathrm{NO}_{2}\right)$ concentration by the Griess assay (Green et al., 1982). Griess reagent (100 $\mu$ ) (a $1: 1$ mixture of $1 \% p$-aminobenzenesulfonamide in $5 \% \mathrm{H}_{3} \mathrm{PO}_{4}$ and $0.1 \%$ naphthylethyl-enediaminedihydrochloride in $\mathrm{H}_{2} \mathrm{O}$ ) were added $(\mathrm{v} / \mathrm{v})$ to diluted samples and standard $\left(\mathrm{NaNO}_{2}\right)$ in 96-well plates. Plates were incubated at room temperature for $10 \mathrm{~min}$ and absorbance was measured at $550 \mathrm{~nm}$ in an ELISA reader.

\section{Electrophoretic mobility shift assay}

The activation of NF-kB was assayed by gel mobility shift assay using nuclear extracts from control and treated cells. Nuclear extract was prepared as described (Park and Park, 2001). As a probe for the gel retardation assay, an oligonucleotide containing the $\kappa$ chain binding site $(\kappa B$, 59-CCGGTTAACAGAGGGGGCTTTCCGAG-39) was synthesized. The two complementary strands were annealed and labeled with $\left[\alpha-{ }^{32} \mathrm{P}\right] \mathrm{dCTP}$. Labeled oligonucleotides $(10,000 \mathrm{cpm})$, $10 \mathrm{mg}$ of nuclear extracts, and binding buffer $(10 \mathrm{mM}$ Tris- $\mathrm{HCl}, \mathrm{pH} 7.6,500 \mathrm{mM} \mathrm{KCl}, 10 \mathrm{mM}$ EDTA, 50\% glycerol, $100 \mathrm{ng}$ poly(dl·dC), $1 \mathrm{mM}$ DTT) were incubated for $30 \mathrm{~min}$ at room temperature in final volume of $20 \mu$ l. The reaction mixture was analyzed by electrophoresis on a $4 \%$ polyacrylamide gel in $0.53 \times$ Trisborate buffer. The gel was dried, and followed by autoradiography. Specific binding was controlled by competition with a 50 -fold excess of cold $\kappa B$ oligonucleotide.

\section{Quantitation expression of iNOS by reverse transcription-PCR (RT-PCR)}

Total RNA was isolated from cells by using TRIzol reagent following the manufacture's instructions. One microgram of total RNA was transcribed into cDNA in a $20 \mu \mathrm{l}$ final volume of reaction buffer $(10 \mathrm{mM}$ Tris- $\mathrm{HCl}, 50 \mathrm{mM} \mathrm{KCl}, 1.5 \mathrm{mM} \mathrm{MgCl} 2,1 \mathrm{mM}$ each dNTP and $2.4 \mu \mathrm{M}$ oligo-d(T) 16-primer, 1 units RNase inhibitor, and 2.5 units M-MLV RNase H-reverse transcriptase by incubation for $10 \mathrm{~min}$ at $21^{\circ} \mathrm{C}$ and $15 \mathrm{~min}$ at $42^{\circ} \mathrm{C}$. The reaction was stopped by incubation at $99^{\circ} \mathrm{C}$ for $5 \mathrm{~min}$. For rat iNOS, PCR aliquots of the synthesized CDNA were added to a $45 \mu \mathrm{PCR}$ mixture containing $10 \mathrm{mM}$ Tris- $\mathrm{HCl}, 50 \mathrm{mM}$ $\mathrm{KCl}, 1.5 \mathrm{mM} \mathrm{MgCl}, 0.2 \mathrm{mM}$ each dNTP, and 2 units Taq DNA polymerase, and $0.4 \mu \mathrm{M}$ of each PCR primer: upstream primer, 5'-CCACAATAGTACAATACTACTTGG-3', down stream primer, 5'-ACGAGGTGTTCAGCGTGCTCCACG-3'. Amplification was initiated with $3 \mathrm{~min}$ of denaturation at $94^{\circ} \mathrm{C}$ followed by 26 cycles at $94^{\circ} \mathrm{C}$ for $1 \mathrm{~min}, 60^{\circ} \mathrm{C}$ for $1 \mathrm{~min}, 72^{\circ} \mathrm{C}$ for $1 \mathrm{~min}$. After the last cycle of amplification, the samples were further incubated for $5 \mathrm{~min}$ at $72^{\circ} \mathrm{C}$. $\beta$-actin PCR was performed with $2.5 \mu$ of aliquots of synthesized cDNA using primers at a concentration of $0.15 \mu \mathrm{M}$ : upstream primer, 5'-TGCCCATCTATGAGGGTTACG-3' down stream primer, 5'-TAGAAGCATTTGCGGTGCACG-3'. The obtained PCR products were analyzed on ethidium bromide-stained agarose $(1.5 \%)$ gels.

\section{Quantitation of expression of iNOS by Western blotting}

Cells were homogenized in $100 \mathrm{ml}$ of ice-cold lysis buffer $(20 \mathrm{mM}$ Hepes, pH 7.2, 1\% Triton X-100, 10\% glycerol, $1 \mathrm{mM}$ PMSF, $10 \mu \mathrm{g} / \mathrm{ml}$ leupeptin, $10 \mu \mathrm{g} / \mathrm{ml}$ aprotinin). The homogenates containing $20 \mu \mathrm{g}$ of protein were separated by SDS-PAGE with $10 \%$ resolving and $3 \%$ acrylamide staking gel, and transferred to nitrocellulose sheets (Schleicher \& Schuell, Germany) in a Western blot apparatus (Bio-Rad, Germany) run at $50 \mathrm{~V}$ for $2 \mathrm{~h}$. The nitrocellulose paper was blocked with $2 \% \mathrm{BSA}$ and then incubated for 4 $\mathrm{h}$ with $1 \mu \mathrm{g} / \mathrm{ml}$ anti-mouse macrophage iNOS rabbit IgG (Transduction Lab.). The binding of antibody was detected with anti-rabbit IgG conjugated with alkaline phosphatase (Sigma). Immunoblots were developed using BCIP/NBT solution (Pierce).

\section{Result and Discussion}

Proinflammatory cytokines, such as IL-1 $\beta$, IFN- $\gamma$ and TNF- $\alpha$, are known to be released into the islets by activated macrophages and $T$ cells in the early stage of autoimmune diabetes and probably responsible for $\beta$ cell destruction (Mandrup-Poulsen, 1996; Rabinovitch, 1998; Eizirik and Mandrup-Poulsen, 2001). Under 
Table 1. Protective effect of EGCG on IL-1 $\beta / / F N-\gamma$-induced cytotoxicity. RINm5F cells $\left(1 \times 10^{5}\right)$ were cultured with IL-1 $\beta$ and IFN- $\gamma$ in the presence or absence of EGCG for $24 \mathrm{~h}$. The concentrations of cytokines or EGCG used were: IL-1 $\beta, 2 \mathrm{ng} / \mathrm{ml}$; IFN- $\gamma, 100 \mathrm{U} / \mathrm{ml}$; EGCG, 0, 20, $50,100,200 \mu \mathrm{g} / \mathrm{ml}$. The percentage of cells viability after these treatments was determined by the MTT colorimetric assay and calculated as a ratio of $A_{570}$ of treated- and control cells (treated with $0.05 \%$ DMSO). Each value is the mean $\pm S E M$ of four independent experiments.

\begin{tabular}{|c|c|}
\hline Treatment & $\begin{array}{l}\text { Cell viability } \\
\text { (\% of control) }\end{array}$ \\
\hline Control & 100 \\
\hline IL-1 $\beta$ & $89 \pm 5$ \\
\hline $\mathrm{IL}-1 \beta+\mathrm{IFN} \gamma$ & $45 \pm 6$ \\
\hline $\mathrm{IL}-1 \beta+\mathrm{IFN} \gamma+\mathrm{EGCG}(20 \mu \mathrm{g} / \mathrm{ml})$ & $55 \pm 7$ \\
\hline $\mathrm{IL}-1 \beta+\mathrm{IFN} \gamma+\mathrm{EGCG}(50 \mu \mathrm{g} / \mathrm{ml})$ & $67 \pm 6$ \\
\hline IL-1 $\beta+$ IFN $\gamma+E G C G(100 \mu \mathrm{g} / \mathrm{ml})$ & $75 \pm 7$ \\
\hline $\mathrm{IL}-1 \beta+\mathrm{IFN} \gamma+\mathrm{EGCG}(200 \mu \mathrm{g} / \mathrm{ml})$ & $82 \pm 6$ \\
\hline
\end{tabular}

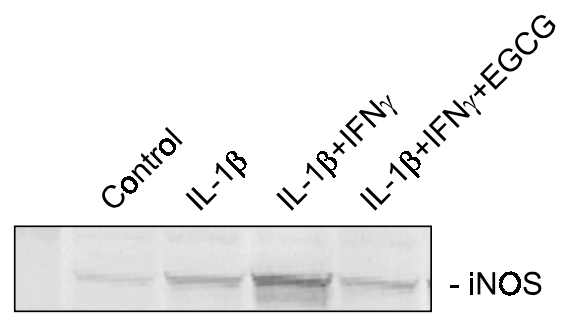

Figure 1. Inhibition of IL-1 $\beta / \mathrm{FN}$ - $\gamma$-induced expression of iNOS from RIN5mF cells by EGCG. RINm5F cells $\left(2 \times 10^{6}\right)$ were cultured with $2 \mathrm{ng} / \mathrm{ml} \mathrm{LL}-1 \beta$ and $200 \mathrm{U} / \mathrm{ml} \mathrm{IFN}-\gamma$ in the absence or presence of $200 \mu \mathrm{g} / \mathrm{ml}$ EGCG for $24 \mathrm{~h}$. Western blotting was performed under the conditions described in "Materials and Methods".

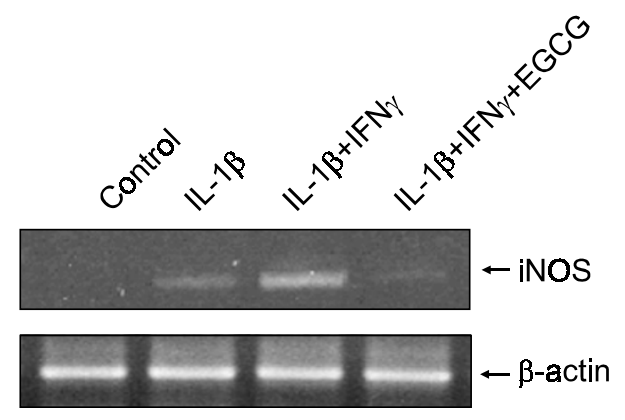

Figure 2. Inhibition of IL-1 $\beta / / F N$ - $\gamma$-induced expression of iNOS mRNA from RINm5F cells by EGCG. RINm5F cells $\left(2 \times 10^{6}\right)$ were cultured with $2 \mathrm{ng} / \mathrm{ml} \mathrm{IL-} 1 \beta$ and $200 \mathrm{U} / \mathrm{ml} \mathrm{IFN}$ - in the absence or presence of $200 \mu \mathrm{g} / \mathrm{ml}$ EGCG for $24 \mathrm{~h}$. RT-PCR was performed as described in "Materials and Methods".

in vitro condition, IL-1 $\beta$ in combination with IFNinduces functional impairment in $\beta$ islets and leads to $\beta$ cell death, mostly by apoptosis (Eizirik and Darville,
Table 2. Inhibition of IL-1 $1 / / \mathrm{FN}-\gamma$-induced release of NO from RINm5F cells by EGCG. RINm5F cells $\left(4 \times 10^{5}\right)$ were cultured with IL-1 $\beta$ and IFN- $\gamma$ in the presence or absence of protector (EGCG) for $24 \mathrm{~h}$. The concentrations of cytokines or protector used were the same conditions in Figure 1. Nitrite concentration was measured in the cell-free culture supernatants as a reflection of NO synthesis. Results of triplicate samples were expressed as mean \pm SEM.

\begin{tabular}{lc}
\hline \multicolumn{1}{c}{ Treatment } & Nitrite $(\mathrm{mM})$ \\
\hline Control & $24 \pm 3.1$ \\
$\mathrm{IL}-1 \beta$ & $22 \pm 5.2$ \\
$\mathrm{IL}-1 \beta+\mathrm{IFN} \gamma$ & $60 \pm 6.1$ \\
$\mathrm{IL}-1 \beta+\mathrm{IFN} \gamma+\mathrm{EGCG}(20 \mu \mathrm{g} / \mathrm{ml})$ & $55 \pm 7.3$ \\
$\mathrm{IL}-1 \beta+\mathrm{IFN} \gamma+\mathrm{EGCG}(50 \mu \mathrm{g} / \mathrm{ml})$ & $47 \pm 6.3$ \\
$\mathrm{IL}-1 \beta+\mathrm{IFN} \gamma+E G C G(100 \mu \mathrm{g} / \mathrm{ml})$ & $35 \pm 7.5$ \\
$\mathrm{IL}-1 \beta+\mathrm{IFN} \gamma+\mathrm{EGCG}(200 \mu \mathrm{g} / \mathrm{ml})$ & $28 \pm 6.3$ \\
\hline
\end{tabular}

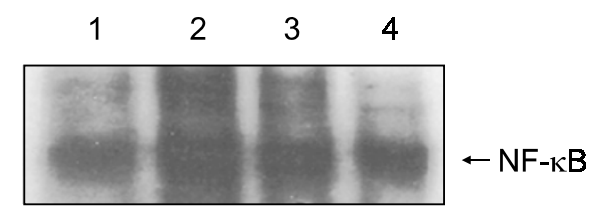

Figure 3. Effect of EGCG on IL-1 $\beta$ and IFN- $\gamma$-induced translocation of NF-KB from cytosol to the nucleus. RIN5mF cells $\left(5 \times 10^{6}\right)$ were treated with cytokines in the presence or absence of EGCG. Following 30 min incubation, nuclear extracts were prepared and NF-KB activation was analyzed by electrophoretic mobility shift assay as described in "Materials and Methods". Lane 1, control; lane 2, IL-1 $\beta+$ IFN- $\gamma$; lane 3, IL-1 $\beta+$ IFN- $\gamma+$ EGCG $(100 \mu \mathrm{g} / \mathrm{ml})$, lane $4, \mathrm{IL}-1 \beta+\mid \mathrm{FN}-\gamma+$ EGCG $(200 \mu \mathrm{g} / \mathrm{ml})$.

2001; Eizirik and Mandrup-Poulsen, 2001).

The effect of EGCG against cytokine-induced $\beta$-cell damage was examined by analyzing cell viabilities of RINm5F cells following the treatment with $\mathrm{IL}-1 \beta$ and IFN- $\gamma$ with MTT assay. As shown in Table 1 , when the RINm5F cell were treated with IL-1 $\beta(2 \mathrm{ng} / \mathrm{ml})$ in the presence of IFN- $\gamma(200 \mathrm{U} / \mathrm{ml})$, almost half $(55 \%)$ of the cells became apoptotic, but IL-1 $\beta$ alone had a minimal effect in cell viability ( $82 \%$ of control). However, pretreatment of the cells with EGCG resulted in no cell death in a dose-dependent manner. At a dose of $200 \mu \mathrm{g} / \mathrm{ml} \mathrm{EGCG}$, the IL-1 $\beta$ and IFN- $\gamma$ induced RINm5F cell death was nearly completely blocked. EGCG treatment alone showed no effect on $\beta$ cell (data not shown).

IL- $1 \beta / / F N-\gamma$ induced release of Nitric Oxide (NO) was shown to mediate cytotoxicity (Rabinovitch and Suarez-Pinzon, 1998). We have explored possible effect of EGCG on NO released from RINm5F cells treated with IL-1 $\beta(2 \mathrm{ng} / \mathrm{ml})$ in the presence of IFN- $\gamma$ $(200 \mathrm{U} / \mathrm{ml})$. As shown in Table II, when RINm5F cells were exposed to IL-1 $\beta$ (2 $\mathrm{ng} / \mathrm{ml})$ and IFN- $\gamma(200$ 
$\mathrm{U} / \mathrm{ml}$ ), there was an approximately 3 fold increase in nitrite levels. However, the increase in nitrite levels was completely abrogated by the pretreatment of cells with EGCG $(200 \mu \mathrm{g} / \mathrm{ml})$. This finding suggests that EGCG induced neutralization of NO produced by cytokine-induced RINm5F cells may be one of the mechanisms EGCG's functions. On the other hand, the inhibition of NO production by EGCG might be due to either the inhibition of iNOS activity or the inhibition of iNOS expression. To test these possibilities, we analyzed expression level of iNOS in the EGCG treated cells by Western blot analysis. The data given in Figure 1 showed that $\mathrm{IL}-1 \beta$ in the combination with IFN- $\gamma$ markedly increased iNOS protein level and the cytokine-induced increase in iNOS protein level was completely blocked by the pretreatment of cells with EGCG $(200 \mu \mathrm{g} / \mathrm{ml})$. The inhibition of NO production by EGCG thus appears to be a result of a decrease of total iNOS protein level. Compatible with these observations, EGCG also blocked IL-1 $\beta / I F N-\gamma$-induced iNOS mRNA expression in RIN5mF cells (Figure 2).

iNOS expression are known to be regulated through the activation of NF-kB (Lowenstein et al., 1994). In addition, NF-kB activation induced by cytokine such as IL-1 $\beta$ promote expression of several $\beta$-cell genes, including pro- and anti-apoptotic genes (Rabinovitch and Suarez-Pinzon, 1998). To elucidate the mechanism of IL- $1 \beta / / F N$ - $\gamma$-induced $\beta$-cell damage associated with the activation of $\mathrm{NF}-\mathrm{\kappa B}$, we have determined the NF- $\kappa B$ activation following cytokine treatment of the cells in the presense or the absence of EGCG. Figure 3 showed a representative EMSA radiograph that depicted the ${ }^{32} \mathrm{P}-\mathrm{DNA} / \mathrm{NF}-\mathrm{kB}$ complexes present in the nuclear extracts of the RINm5F cell after treatment of $\mathrm{IL}-1 \beta(2 \mathrm{ng} / \mathrm{ml})$ in the presence of IFN- $\gamma$. Pretreatment with EGCG inhibited IL-1 $\beta / I F N-\gamma$ induced$N F-\kappa B$ activation in a dose dependent manner. At a dose of $200 \mu \mathrm{g} / \mathrm{ml} \mathrm{EGCG}$, the IL-1 $\beta / \mathrm{IFN}-\gamma$ induced$N F-\kappa B$ activation was decreased to a level of the control.

In conclusion, the present results indicate that one of the protective function of EGCG for cytokine-induced $\beta$-cell destruction involves inhibition of $N F-\kappa B$ activation. Thus, this study provides the possibility that EGCG might have a preventive effect on cytokine-induced diabetes.

\section{Acknowledgement}

This paper was supported by Research Funds of Chonbuk National University.

\section{References}

Ahmad F, Khalid P, Khan MM, Rastogi AK, Kidwai JR. Insulin like activity in (-)epicatechin. Acta Diabetol Lat 1989; 26:291-300

Broadhurst CL, Polansky MM, Anderson RA. Insulin-like biological activity of culinary and medicinal plant aqueous extracts in vitro. J Agric Food Chem 2000;48:849-52

Eizirik DL, Darville Ml. $\beta$-cell apoptosis and defense mechanisms: lessons from type 1 diabetes. Diabetes 2001;50 Suppl. 1:S64-9

Eizirik DL, Mandrup-Poulsen T. A choice of death--the signaltransduction of immune-mediated $\beta$-cell apoptosis. Diabetologia $2001 ; 44: 2115-33$

Green LC, Wagner DA, Glogowski J, Skipper PL, Wishnok JS, Tannenbaum SR. Analysis of nitrate, nitrite, and $\left[{ }^{15} \mathrm{~N}\right]-$ nitrate in biological fluids. Anal Biochem 1982;126:131-8

Kao YH, Hiipakka RA, Liao S. Modulation of endocrine systems and food intake by green tea epigallocatechin gallate. Endocrinology 2000;141:980-7

Katiyar SK, Mukhtar H. Tea antioxidants in cancer chemoprevention. J Cell Biochem Suppl 1997;27:59-67

Lowenstein CJ, Dinerman JL, Snyder SH. Nitric oxide: a physiologic messenger. Ann Intern Med 1994;120:227-37

Mandrup-Poulsen T. The role of interleukin-1 in the pathogenesis of IDDM. Diabetologia 1996;39:1005-29

Nakayama M, Suzuki K, Toda M, Okubo S, Hara $Y$, Shimamura T. Inhibition of the infectivity of influenza virus by tea polyphenols. Antiviral Res 1993;21:289-99

Park BH, Park JW. The protective effect of Amomum xanthoides extract against alloxan-induced diabetes through the suppression of NF-kB activation. Exp Mol Med 2001;33:64-8

Rabinovitch A. An update on cytokines in the pathogenesis of insulin-dependent diabetes mellitus. Diabetes Metab Rev 1998;14:129-51

Rabinovitch A, Suarez-Pinzon WL. Cytokines and their roles in pancreatic islet $\beta$-cell destruction and insulin-dependent diabetes mellitus. Biochem Pharmacol 1998;55:1139-49

Tannous M, Amin R, Popoff MR, Fiorentini C, Kowluru A. Positive modulation by Ras of interleukin-1b-mediated nitric oxide generation in insulin-secreting clonal beta (HIT-T15) cells. Biochem Pharmacol 2001;62:1459-68

Yang CS, Wang ZY. Tea and cancer. J Natl Cancer Inst 1993;85:1038-49 